KRITIKE VOLUME FOUR NUMBER ONE (JUNE 2010) 123-137

Article

\title{
No Name: Paul Celan's Poetics of Naming
}

Antti Eemeli Salminen

$\mathrm{N}$

ame is a powerful sign, and name-giving is also calling one into language. Name identifies, summons and subjects. Paul Celan was

familiar with all these uses of name and addresses them in his poetics and poetry. This article will discuss how poetry like Celan's, which is heavily influenced by so many philosophical readings, could form a critique of naming, on a poetical basis towards philosophical concepts that underline problematics of name-giving in poetic text in particular.

"We bear the sparkle, the pain and the name," Celan wrote in the poem "White and light" ("Weiß und Leicht"). ${ }^{1}$ For Celan, it seems, one's name was an inevitably burden to carry. Celan's posthumous fragment is a trace to be followed in order to alleviate that burden:

$$
\begin{aligned}
& \begin{array}{l}
\text { Anonyme, namenlose Poesie. Der Dicht[un]g } \\
\text { innewohnender Hang zum Namenlosen }-^{2}
\end{array} \\
& \begin{array}{l}
\text { Anonymous, nameless poetry. Inner desire of the } \\
\text { [poetry] for the namelessness }-{ }^{3}
\end{array}
\end{aligned}
$$

The anonymous and namelessness may not exactly mean the same here. Anonymity detaches itself from names, but namelessness may carry a hidden or unnamable name. The article further discusses how Celan addresses both aspects in his life, poetry and poetics.

Although Celan has stated that "poetry is anti-biographic," 4 it must be noted that naming and name-plays had a special role in his own life. First Celan changed his name to Paul Aurel, then to Paul Ancel, and finally anagrammed his nom de plume to Paul Celan. Naming otherwise is the inverse of anonymity: an alias that one gives oneself obliterates the former name, thus renaming and rebuilding the identity. Hence Celan used his name as a mask: a new name hid an older one, and naming again served as a gesture of unnaming.

\footnotetext{
1 Paul Celan, Gesammelte Werke in Fünf Banden (Frankfurt am Main: Suhrkamp Verlag, 1983), I, 165. [Cited as GW I-V]

2 Paul Celan, Mikrolithen sinds, Steinchen. Die Prosa aus dem Nachlass (Frankfurt am Main: Suhrkamp Verlag, 2005), 112.

3 All translations by the author, unless otherwise stated.

${ }^{4}$ Celan, Mikrolithen sinds, Steinchen, 95.
} 


\section{NO NAME}

Silvia Baier even claims that Celan ultimately declared himself in the Odysseian fashion Nobody and approached the sphere of nothingness in his personal life as also in his poems. ${ }^{5}$

Nonetheless it seems evident that Celan was acutely aware of the logic of anonymity and unnaming, also through his own experience. Celan's ambiguous naming practices are obvious in his posthumous fragment, which plays with the multiplicity of his own name: "My name - Celan, Célañ, Zelan. -." 6 Self-naming is also a form of autonomy, and for Celan searching for this autonomy became a poetic practice, too. According to Silvia Baer, Celan even took a conscious position as "nobody," in order to create a new self by destruction of the old identity and name. ${ }^{7}$ As will be discussed later, this ageold motif of Nobody meant much to Celan.

Besides subjective identity-play, there is also a philosophical undercurrent that stems from the thinking of Martin Heidegger, which Celan was familiar with. The Heideggerian problem of naming stems from the question of presence. To name is to represent, and thus the name conceals the real presence of beings and Being. As Heidegger writes in the famous passage of The Anaximander Fragment.

As soon as presencing is named, it is represented as some present being. The essence of presencing [Das Wesen des Anwesens], and with it the distinction between presencing and what is present, remains forgotten. The oblivion of being is the oblivion of the distinction between Being and beings. ${ }^{8}$

The desire for namelessness also resonates with Heidegger's passage in Wrong Paths, which Celan knew and underlined in his copy of the book: ${ }^{9}$

If man is once again to come into the vicinity of Being [die Nähe des Seins], he must first learn to exist in namelessness [Namenlosen]. He must recognize equally the seduction of the public and the powerlessness of the private. Before he speaks, he must allow himself again to be spoken to by Being and risk the danger that in being

5 Silvia Baier, Nobody's voice: Constructions of poetic identity in Celan, Rilke and Bachmann (New York: Columbia University Press, 2006), 12.

${ }^{6}$ Celan, Mikrolithen sinds, Steinchen, 116.

${ }^{7}$ Baier, op cit.

${ }^{8}$ Martin Heidegger, Early Greek Thinking, trans. by David Farrell Krell and Frank A. Capuzzi (San Francisco: Harper \& Row, 1975), 50-51.

${ }^{9}$ Paul Celan, La bibliothèque philosophique / Die philosophische Bibliothek. Catalogue raisonné des annotations, ed. by Alexandra Richter, Patrik Alac, Bertrand Badiou (Paris: Éditions Rue d'Ulm, 2004)411); James L. Lyon, Paul Celan and Martin Heidegger: An Unresolved Conversation 1951-1970 (Baltimore: The Johns Hopkins University Press, 2006), 31. 
spoken to he will have little or rarely have something to say. ${ }^{10}$

Following Heidegger's discussion, the anonymity of Celan's language is in the state of tension between "the seduction of the public and the powerlessness of the private." Considering that the question inevitably arises how Celan's poetics articulates namelessness, and how, despite an inclination towards namelessness, his poetry is able to speak in its singular voice.

\section{From Mystical to Ethical Naming}

The idea of nameless poetry and its namegiving is definitive in Celan's Meridian speech (delivered 1960):

Gehuldigt wird hier der für die Gegenwart des Menschlichen zeugenden Majestät des Absurden. Das, meine Damen und Herren, hat keinen ein für allemal feststehenden Namen, aber ich glaube, es ist... die Dichtung. ${ }^{11}$

It is homage to the majesty of the absurd which bespeaks the presence of human beings. This, ladies and gentlemen, has no definitive name, but I believe that this is... poetry. ${ }^{12}$

As the meaning of poetry goes with "no definite name" Celan's poetics is bound to the unnamable, but not necessarily to sheer anonymity. It is not impossible that the definitive name for poetry and "the presence of human being" could be given. Perhaps Celan hesitatingly only "believes" as he is well aware that the name reduces beings to their names.

It is evident and has been noted many times before ${ }^{13}$ that name and naming is not only a question of identity or personality for Celan. In his groundbreaking study Magie der Form (1980), Winfried Menninghaus connects Celan's use of the word "Name" to the language of mysticism. According to Menninghaus the mystical yet self-reflective undercurrent in Celan's poetry stems from the unsayability of the name, which is a recurring theme in both Jewish and Christian apophatic traditions, which Celan studied in depth. ${ }^{14}$ It is

10 Translated in Lyon, ibid; Original in Heidegger, Wegmarken. Gesamtausgabe, vol. 9 (Frankfurt: Klostermann, 1976), 319.

11 GW III, 190 [emphasis added]

12 Translated in Pierre Joris, Paul Celan: Selections (London: University of California Press, 2005), 157. [emphasis added]

13 See, for example, Dietlind Meinecke, Wort und Name bei Paul Celan. Zur Widerruflichkeit des Gedichts (Bad Homburg: Verlag Gehlen, 1970) and Winfried Menninghaus, Magie der Form (Frankfurt am Main: Suhrkamp Verlag, 1980). 2001), 180-181.

${ }^{14}$ John Felstiner, Paul Celan - Poet, Survivor, Jew (New Haven: Yale University Press, 


\section{NO NAME}

evident that with the Homeric "I am No-one," the Biblical "I am that which is" is an another point of departure of Celan's poetics of anonymity.

In the case of anonymity the name is not only a metapoetical issue as Menninghaus suggests, but has to do with the "naming power" of language itself. This being so, it is no surprise that gestures of anonymity and unnaming craft Celan's poetics on the fundamental level. As William Franke states, whatever is named is in some manner possessed, but against this possession Celan's poetry stems from a silent source of language, which serves as an anonymous foundation for all constructions of names. ${ }^{15}$ Thus anonymity comes before the names, but it also calls them forth. Anonymity and naming are in constant flux as in the poem "The Written": "in the liquified names / the dolphins dart." 16

In the Flinker letter ${ }^{17}$ Celan states that poetry "names and posits [nennt und setzt t, and endeavours to measure out the domain of what is given and what is possible." 18 Thus naming to some extent is inevitable even in poetry, and considering his poetics of anonymity Celan accepts these gestures of necessity. But if and when Celan's poems give names, they name according to their own terms, which are often contrary to ordinary naming that grounds identities and possesses the named. Anne Carlston deems it plausible that loss, death, and absence are the points of departure of Celan's naming. ${ }^{19}$ Perhaps Carlston's thinking could be taken further with the Heideggerian critique. Naming is death to beings as such. Only a being without a name can be fundamentally free, even from language.

One of the most obvious and researched representations of the theme of anonymity is Celan's play with the theme and the word "No-one" [Niemand], which reaches its zenith in the anthology Niemandsrose and the prose piece Gespräch im Gebirg. Hannes Fricke traces Celan's use of this classical topos of anonymity back to the works of Kafka, Picasso and Mandelstam. ${ }^{20}$ Celan's Jewish heritage is not to be underestimated here. As Fricke observes, Celan's Niemand is also a mystical theme, as it is forbidden to pronounce the name of the Jewish God, Tetragrammaton, which is a conception of the utmost importance especially from the Kabbalistic point of view, into which Celan was thoroughly initiated. ${ }^{21}$ No-one may be the coreless core of Celan's unnamability motif, but it is far from complete anonymity, as will be discussed further.

15 William Franke, "The Singular and the Other at the Limits of Language in the Apophatic Poetics of Edmond Jabès and Paul Celan," in New Literary History, 36 (2005), 629.

16 Original in GW II, 75.

${ }^{17}$ Reply to a Questionnaire from the Flinker Bookstore, 1958.

18 GW III, 167.

19 Anne Carlston, "Defiance and Reconciliation in Paul Celan's Die Niemandsrose," in Borders, Exiles, Diasporas, ed. by Elazar Barkan and Marie-Denise Shelton (Palo Alto: Stanford University Press, 1998), 118.

${ }^{20}$ Hannes Fricke, Niemand wird lesen, was ich bier schreib: über den Niemand in der Literatur (Göttingen: Wallstein, 1998), 369.

$$
{ }^{21} \text { Ibid., } 375 .
$$


The thematic of anonymity can be also seen in the historical context Celan's poetry stems from: from the modern Jewish viewpoint anonymity invokes the Holocaust, the theme which is echoed in many Celan's poems. In the concentration camps the names of Jewish inmates were replaced with numbers tattooed on their left forearms. Thus the Jews were dehumanized at the same time by anonymizing and being renamed by an extra-linguistic and technical system. The inmates were both unnamable and anonymous at the same time, but also haunted by the numeric no-name. Usually names remain after death, but when Celan's language survived through the "thousand darknesses of death-bringing speech" of the Nazi era as he states in the Bremen speech, ${ }^{22}$ the names of the Jewish victims perished in the Holocaust. In this respect Felstiner states that the German word Name pervades Celan's writing, in order to restore identity to those deprived of it. ${ }^{23}$

Paradoxically enough Name appears anonymous in Celan's poetry, like a question without an answer: "Wer nennt ihren Namen zuerst? [...]Der nennt ihren Namen nicht." (from "Erinnerung an Frankreich").24 In many cases the true moment of anonymity is a condition of encounter with "you," as in "Black":

Das Namengeben hat ein Ende, über dich werf ich mein Schicksal. ${ }^{25}$

The namegiving had an end, over you I cast my fate.

That said, the thematic of anonymity has ethical undercurrents beside the mystical and biographic overtones. As discussed later, anonymity appears as a nexus of Celan's poetics, which outlines what can be represented and said by poetic means.

\section{Between the Anonymity and the Name}

Proper names in Celan's poetry are rare, but not totally absent. Often they lead beyond individuals and are rarely mentioned directly. In the poem "Coagula" the name "Rosa" is mentioned: "Also your / wounds, Rosa." Judging simply by the poem's explicit context the addressee is the assassinated Rosa Luxemburg. In addition the name refers to Celan's old love, a Communist militant from Bucharest, but also to Kafka's novel "A Country Doctor," which contains the wounded Rosa as a character ${ }^{26}$. Yet there is more: in the context of the poem rosa also refers to the rose mysticism and the "red

\footnotetext{
22 GW III, 186.

${ }^{23}$ Felstiner, op cit., 64.

${ }^{24}$ GW I, 28.

${ }^{25}$ GW II, 57.

${ }^{26}$ Felstiner, op cit., 224.
} 


\section{$128 \quad$ NO NAME}

phase" of the alchemistic process. ${ }^{27}$ "Rosa" exemplifies how names can function in an inverted manner: the name anonymizes and veils as it alludes to multiple directions and persons at the same time. This paradoxical logic Werner Hamacher extrapolates in his essay on an another anonymizer close to Celan, Franz Kafka:

In every [Kafka's] name a ruinous antonomasia is at work. Just as every language means too much, every name names too much, overnames, and thus de-names. Every name anonymizes. ${ }^{28}$

Naturally in Celan's poetry there are more direct and less ambiguous namings than Rosa the Militant Alchemist from Bucharest, but these are always the names that matter. In "Largo" Martin Heidegger's name is inscribed in the adverbially used neologism "heidegängerisch." In the poem "To one who stood before the doors," Rabbi Löw (d. 1619) is mentioned in an overtly Kabbalistic context as well as the biblical figures of Abraham and Jacob in "Radix, matrix." The poets Hölderlin and Mandelstam are for their part mentioned with Celanian puns. Thus proper names are not usually genuinely proper as they "overname" and "de-name" individual and often historical persons.

Almost the only names that are easily recognized in Celan's poetry are the names of places, plants and animals. Celan draws names from botanical and zoological sources: Augentrost ("Todtnauberg"), Eisvogel ("Stimmen") or Espenbaum ("Espenbaum"), are without doubt names, but not for single beings. The species are named, but within them particular entities remain anonymous. Place names could be counted as an exception; many of them from Siberia to Paris and from the Eden to Babel are mentioned. Perhaps the names of natural objects and geographical places were those which remained uncorrupted in the havoc of the Nazi era and, as non-human names, escaped the hostile anonymization.

But although there is an explicit thrust as well as "inner desire" towards anonymity, Celan cannot altogether escape the processes of naming, due to the very nature of the German language. As Erin G. Carlston observes, we find in Celan's work an enormous number of verbs, past participles, and adjectives transformed into nouns, which are structurally equal in German to proper names as they begin with capital letters. ${ }^{29}$ Conversely, this could also count as criticism of the naming power: names are given to entities which do not normally have them, the practices of naming become more visible.

Regarding Celan's poetics in published speeches and posthumous fragments, Celan uses many fundamental concepts to design his poetics that

27 Anders Olson, "Spectral Analysis. A commentary on 'Solve' and 'Coagula'," trans. by Hanna Kalter Weiss, in Word Traces (Baltimore: Johns Hopkins University Press, 1994), 269.

${ }_{28}$ Werner Hamacher, Premises: Essays on Philosophy and Literature from Kant to Celan (Stanford: Stanford University Press, 1999), 316.

${ }^{29}$ Carlston, op cit., 118. 
are either unnamable or anonymous. These "unnames" include $U$-topia, ${ }^{30}$ other and Other [Andere], nothingness [Nichts], one, No one [Niemand] and the often addressed you (singular and plural) who remains almost without exception anonymous. Particularly in the cases of other, no-one and U-topia the entities in question cannot be separated from their names, because they lack attributes. But as the unnames are identified in language, they cannot completely escape naming. These unnames, too, are at risk of becoming someone particular or something identifable; soon U-topia is placed on the map and nothingness gives rise to something particular.

Yet unnames can have crucial poetic significance. Rochelle Tobias has identified unnaming as a key term in Celan's prose piece Gespräch im Gebirg. In the text unnaming is also considered to be criticism of representation:

The unspeakability of the name guarantees that it can never be put to the service of representation; it saves the name from ever representing or being represented. Its unspeakability, thus, preserves its singularity. ${ }^{31}$

But as language lives, the unspeakability topos is not static, but only a temporary position. A short but illuminating example of how the unname and the name melt in to one can be found in the excerpt of the Celan's longest poem "Straitening":

Der Ort, wo sie lagen, er hat

einen Namen - er hat

keinen. ${ }^{32}$

The place where they lay, it has

a name - it has

none. ${ }^{33}$

The logic of the unnamable is paradoxical here. The place has a name, but the name is unnamable or even non-existent. The nameless name locates the placeless place also in language, too: through unnamability the poem opens up a domain of its own. With a paradox and unnaming a u-topia of the poem's own is created. Another reading would be that the name is overwritten or erased by the dash.

The real Celanian locus classicus of the dynamics of anonymity comes from the poem "Psalm," in which there is an another type of negative namegiving in progress:

\footnotetext{
30 The extraordinary hyphen Celan uses in the word is a matter of speculation.

31 Rochelle Tobias, "The Ground Gives Way: Intimations of the Sacred in Celan's 'Gespräch im Gebirg',' in MLN, 114 (1999), 583.

32 GW I, 195.

33 Translated in Paul Celan, Poems of Paul Celan. Revised \& Expanded, trans. by Michael Hamburger (New York: Persea books, 2002), 115.
} 
Niemand knetet uns wieder aus Erde und Lehm, niemand bespricht unseren Staub.

Niemand.

Gelobt seist du, Niemand. ${ }^{34}$

No one kneads us again out of earth and clay, no one incants our dust.

No one.

Blessed art thou, No one. ${ }^{35}$

As has often been observed, the indefinite pronoun no-one becomes a nameless name No-one and the addressee of the poem. As Baier plausibly remarks, Celan's Nobody becomes a third term between I and you, yet it is dependent upon both. ${ }^{36}$ The same goes for Celan's poetics of anonymity, as it builds a space in-between and beyond naming and unnaming.

But the most crucial is not the meaning of this name-becoming as such, but the radical ambivalence of the third line, in which no-one and Noone blend together in the grammatical metamorphosis. The fourth line is a place in-between anonymity and nameless name: the ambiguity is unresolved. The single word in this special context is in a state of becoming. After the fourth line, with an abrupt stop, the gap between stanzas appears like a curtain that hides this naming process. The outcome is hailed in the next line: the Noone has come. As in magical thinking the invoking of the name calls the person mentioned, but with Celan's inversive gesture the anonymity and negation (no-one) invoke the unnamable No-one, a hollow name that takes a the place of the deity. Considering the third version of the poem, dated January 1961, Celan has written the addressee in lower case letters. ${ }^{37}$ Thus the writing process of "Psalm" itself has included this name-becoming. A negation has been rendered to name even while the time Celan was writing his poem. Hence in "Psalm" identity is given to anonymity (and vice versa), for whom the name is no burden, but who pays homage to the long tradition of No-ones, from Odyssey the Nemo onwards.

By these means Celan's writing opposes conventional naming and ultimately the representional function of the name. The "place" of the "Straitening" and the third line in "Psalm" remains in-between anonymity and the name. These in-betweens also appear in the poem "It is no longer" in a

${ }^{34}$ GW I, 225

35 Translated in Paul Celan, Selected Poems and Prose of Paul Celan, trans. by John Felstiner (New York: Norton, 2001), 157.

${ }^{36}$ Baier op cit., 14.

37 Paul Celan, Niemandsrose, Tübinger Ausgabe, ed. by Jürgen Wertheimer et al. (Frankfurt am Main: Suhrkamp Verlag, 1996), 35. 
more complicated and thematized manner, as the latter strophe of the poem reads:

Es ist das Gewicht, das die Leere zurückhält, die mit-

ginge mit dir.

Es hat, wie du, keinen Namen. Vielleicht

seid ihr dasselbe. Vielleicht

nennst auch du mich einst

so. ${ }^{38}$

It is the weight holding back the void

that would

accompany you.

Like you, it has no name. Perhaps

you two are one and the same. Perhaps

one day you also call

me so. ${ }^{39}$

The addressee and "the void" are unnamable. This namelessness builds an identity between you and the void: an identity of a non-identity. Perhaps the same goes for the speaker, who joins "you" and the void in anonymity. Again this is a form of encounter in the name of the unnamable, when the hinges of identities are "one day" loosened.

As a concluding example, the double anonymities of U-topia and Noone come together in the poem "There was earth inside them" as the following question: "O one, o none, o no one, o you: / Where did it go then, making for nowhere?"40 In the Celanian manner the question remains open, because the answer would name the place and posit the no-one as someone. In this question the same transfiguration is at work as in the passage of "Psalm" quoted earlier: an undefined pronoun ("one") becomes "you" with two kinds of negations ("none," "no one"). In this question the gradual addressing is followed by a paradoxical riddle. As the unnamed addressee comes from nowhere, she could be the right person to answer the riddle. But no-one answers. Or does No-one?

\section{Gestures of Anonymity}

Celan's poetry moreover makes visible and problematizes naming with unnames, there are also writing strategies that quite directly criticize the naming power of language by means of dating, orthographic practices and ostension. In his essay "Shibboleth for Paul Celan" Jacques Derrida brings forward Celan's habit

\footnotetext{
$38 \mathrm{GW}$ I, 238

39 Translated in Celan, Poems of Paul Celan, 163.

${ }^{40}$ Translated in Celan, Selected Poems and Prose of Paul Celan, 135; Original in GW I, 211.
} 


\section{NO NAME}

of dating all of his poems. The date posits the poem in time and gives it a temporal identity that according to Derrida, resembles and functions like a proper name. ${ }^{41}$ But the date-name is bound to the anonymity as the date names only the single day, that has vanished in the past. Despite this becominganonymous the trace of the date-name remains in the poem, and actually Derrida even states that "this trace is the poem." 42 Names and anonymity are fundamentally temporal functions of language and the poetic. That is why not even anonymity can ever completely withdraw from the practices of naming. As the unnamable names, the anonymous too is at risk of being named, and vice versa.

Secondly Celan "names without naming" with an ostensive gesture. Usually only concrete objects or persons are named in this way ("Look, Anna is there"), but, surprisingly enough, Celan also names with ostensive definitions the usually unnamable, non-objectivable and even absence as such. In the poem this is possible with a colon, as in the poem "Radix, matrix":

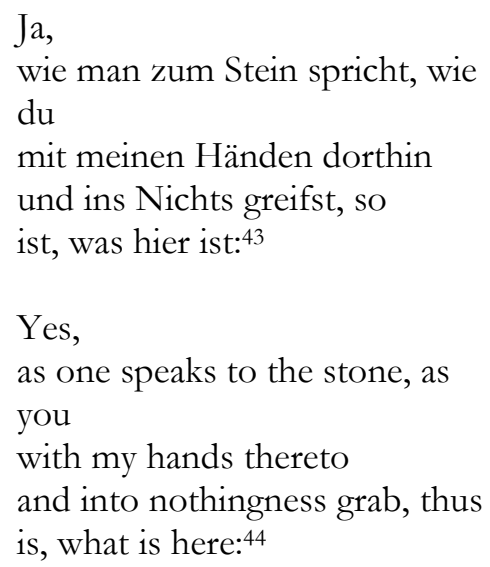

Such ostensive definitions, which are quite typical in Celan's poetry, name without names. They fulfill the function of the name, but do not create one. This form of naming "grasps nothing" as the poem itself thematizes. This is to say that the ostensive "name" is also a position in poem and even in its very materiality. The same kind of positing with the anonymity is illustrated by the last strophes of "Diligents":

$$
\begin{aligned}
& \text { die unbeschriebene Wand } \\
& \text { einer Stehzelle: }
\end{aligned}
$$

${ }^{41}$ Jacques Derrida, Sovereignties in Question: The Poetics of Paul Celan, ed. by Thomas Dutoit and Outi Pasanen, trans. by Dutoit, Pasanen, Joshua Wilner and Philippe Romanski (New York: Fordham University Press, 2005), 17.

42 Ibid., 40.

${ }^{43}$ GW I, 239 .

${ }^{44}$ Translated in Joris, op cit., 84. 


\author{
hier \\ leb dich \\ querdurch, ohne Uhr. ${ }^{45}$ \\ the undepicted wall \\ a standing cell: \\ here \\ live your \\ thirst, without clock.
}

The standing cells were the small cement cells of the concentration camps, in which the prisoners were so squeezed that they could not move at all. As the wall is "undepicted," the poem approaches the limits of representation. This also shows in the German word "unbeschriebene," which is very similar to ungeschriebene, non-written. Thus Celan indicates the cell in his poem, not with direct naming, but pointing its place in the language and the page. The standing cell in language takes the place where the name of "here" ought to be. "Here" is not in "Birkenau" or "Auschwitz," but the anonymous cell is present through the spatial room the poem encompasses. This is a special holding unit in the prison house of language.

Surely the historical context is of the utmost importance in "Diligents": During the Holocaust the names of the victims perished, as they were dehumanized. But the anonymous addressing also shows what cannot be shown - the place where all the names are violently stripped away. As Derrida states, "the unpronounceable keeps and destroys the name; it protects it, like the name of God, or dooms it to annihilation among the ashes."46 "Diligents" reveals the foul side of anonymity, which Celan attains fully only by anonymous expressions. At the edge of the language the names perish, but what is at stake is the singularity of the beings that bear them.

The third gesture of anonymity which Celan uses goes even deeper into the structure of his poems. In his latter collections Celan makes extensive use of an orthographic naming practice, which is structured by the tension between anonymity and namelessness. In his latter collections every poem "names itself" as the first word(s) appear as the name of the poem. Paradoxically enough, these poems have no names, no distinct titles, but still they carry their names within. The no-names, distinct from unnames, which are only unpronounceable or unknown, are integral parts of the poems. Celan's orthographic no-names almost parodies the normal practice of begining the name with a capital. The names, or better, their absence, become overdetermined. Thus the orthographic gesture makes visible the usual

\footnotetext{
${ }^{45}$ GW II, 151.

${ }^{46}$ Derrida, op cit., 50.
} 


\section{NO NAME}

practices of naming. In two poems Celan experiments with this practice on the verge, as he gives overtly anonymous no-names to his poems.

DAS NICHTS, um unsrer

Namen willen

- sie sammeln uns ein -,

siegelt, ${ }^{47}$

NOTHINGNESS, for our

names' sake

- they gather us in -,

sets a seal, ${ }^{48}$

"Nothingness" as a no-name of the poem refers to the theme of anonymity with multiple layers. Firstly, as the nothingness is "for our / names' sake" these names are potentially to be erased, names towards anonymity or oblivion. The nothingness is depicted as a dynamic force as it "sets a seal." Thus its anonymity and names are not only two distinct poles, but in flux: as "No-one" was a name-not-yet, names in "Nothingness" are becoming names-nomore. As in the poem "It is no more" the thematic of nothingness appears in tandem with the poetic practice of anonymity in "Nothingness." This only shows that anonymity is not an isolated theme in Celan's poetry, but it is in the coreless core of his poetic vision and view of language. When the unnamable is unvoiced, the language itself must make room and let the emptiness emerge with its own silence-bound syntax.

If "Nothingness" refers to the anonymity as a theme of the poem, from Celan's oeuvre can be found a still more radical example, which grounds the poem in the sheer anonymity in the material level of the poem:

KEIN NAME, der nennte:

sein Gleichlaut

knotet uns unters

steifzusingende

Hellzelt. ${ }^{49}$

NO NAME, that would name:

its consonance

knots us under the

stiffensongful

lighttent.

${ }^{47}$ GW III, 110.

48 Translated in Celan, Poems of Paul Celan, 371.

${ }^{49}$ GW II, 226. 
Celan underlined the first line of his first version of the poem, which foregrounds the opening line, and also delivers it as a kind of aphorism. 50 "No name" as the no-name, is a paradox that almost paradigmatically depicts Celan's poetics of anonymity. As the "No name" is also the title of the poem, the poem also names itself with a nameless name. What is named with noname may still not be "its consonance" or the whole poem, but the absence after the colon (NO NAME, that would name: ). The "consonance" in question could thus be the consonance of the semantic nothingness and the anonymity at its edge: of the non-existent language. The no-name "No name" thus names the very semantical nothingness of the blank page. As this is done with a colon, both orthographic and ostensive gestures of anonymity are condensed into only four words.

\section{Anonymous Presences}

To sum up, in Celan's poetics there are unnamability and unnames of two kinds, names not yet and names no longer. The first category consists of the name-becomings as in the case of Niemand in "Psalm" and the second includes names like Rosa in "Coagula." Both these unnames are still within the logic of naming, because prospective and forgotten names are names as well. Moreover, Celan uses at least three different uses of anonymity, which escape the naming and power it calls for, but at the same time makes conventional naming processes visible.

The unnames and anonymity in Celan's poetry form a kind of double strategy that concretizes Heideggerian critique of naming at the textual and poetic level. Celan's unnaming and anonymity can ultimately be considered as the critique of the poetic representation and referential views of language. The name is always arbitrary, although it is the primary and definitive sign for a being. Meanwhile anonymity thematizes that there is always something unwritten, a loss between signifier and signified, name and named. But at the same time this absent remainder makes the naming, and even the poem itself, possible. This double bind is shown in "With letter and clock":

Wachs,

Ungeschriebnes zu siegeln,

das deinen Namen

erriet,

das deinen Namen

verschlüsselt. ${ }^{51}$

Wax

50 Paul Celan, Fadensonnen, Tübinger Ausgabe, ed. by Jürgen Wertheimer, Heino Schmull, Markus Heilmann and Christiane Wittkop (Frankfurt am Main: Suhrkamp Verlag, 2000) (2000), 219.

${ }^{51} \mathrm{GW} \mathrm{I}, 154$. 


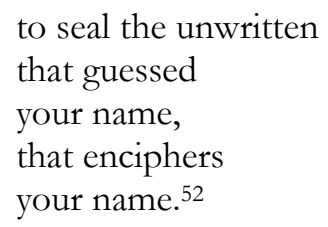

Wax is used for sealing and reproducing: the same wax can both hide and duplicate traces. The wax of the language "guesses" and "enciphers," unfolds and hides our names.

Carlston claims that in Celan's poetry there is an attempt to name everything "liberally" and "profusely," in order "to make everything Jewish." 53 This does not seem evident. On the contrary, Celan is not naming, nor resisting naming. His poetry unnames, denames and anonymizes in the quest to say what there is as such, without claims about fixed identities and kinships. His poems are able, in Heidegger's words we started with, to "exist in namelessness." But this is far from the textual nihilism: something of importance is still signified in his poetry with the anonymous no-names, non-representable presences, as "the vicinity of being" unfolds.

$$
\begin{array}{r}
\text { Department of Literature, University of Tampere, Finland } \\
\text { Researcher, Academy of Finland, Finland }
\end{array}
$$

\section{References}

Baier, Silvia, Nobody's voice: Constructions of poetic identity in Celan, Rilke and Bachmann (New York: Columbia University Press, 2006).

Carlston, Anne, "Defiance and Reconciliation in Paul Celan's Die Niemandsrose," in Borders, Exiles, Diasporas, ed. by Elazar Barkan and Marie-Denise Shelton (Palo Alto: Stanford University Press, 1998).

Celan, Paul Selected Poems and Prose of Paul Celan, trans. by John Felstiner (New York: Norton, 2001).

Der Meridian: Endfassung, Vorstufen, Materialien. Tübinger Ausgabe, ed. by Bernhard Boschenstein and Heino Schmull (Frankfurt am Main: Suhrkamp Verlag, 1999).

Fadensonnen, Tübinger Ausgabe, ed. by Jürgen Wertheimer, Heino Schmull, Markus Heilmann and Christiane Wittkop (Frankfurt am Main: Suhrkamp Verlag, 2000).

Gesammelte Werke in Fünf Banden (Frankfurt am Main: Suhrkamp Verlag, 1983). La bibliothèque philosophique / Die philosophische Bibliothek. Catalogue raisonné des annotations, ed. by Alexandra Richter, Patrik Alac, Bertrand Badiou. (Paris: Éditions Rue d'Ulm, 2004).

\footnotetext{
52 Translated in Celan, Poems of Paul Celan., 83

${ }^{53}$ Carlston, op cit., 117.
} 


\section{A. SALMINEN 137}

Mikrolithen sinds, Steinchen. Die Prosa aus dem Nachlass (Frankfurt am Main: Suhrkamp Verlag, 2005).

Niemandsrose, Tübinger Ausgabe, ed. by Jürgen Wertheimer et al. (Frankfurt am Main: Suhrkamp Verlag, 1996).

Poems of Paul Celan. Revised \& Expanded, trans. by Michael Hamburger (New York: Persea books, 2002).

Derrida, Jacques, Sovereignties in Question: The Poetics of Paul Celan, ed. by Thomas Dutoit and Outi Pasanen, trans. by Dutoit, Pasanen, Joshua Wilner and Philippe Romanski (New York: Fordham University Press, 2005).

Felstiner, John, Paul Celan - Poet, Survivor, Jew (New Haven: Yale University Press, 2001).

Fioretos, Aris, "Nothing: History and Materiality in Celan," in Word Traces, ed. by Aris Fioretos (Baltimore: The Johns Hopkins University Press, 1994).

Franke, William, "The Singular and the Other at the Limits of Language in the Apophatic Poetics of Edmond Jabès and Paul Celan," New Literary History, 36 (2005), 621-638.

Fricke, Hannes, Niemand wird lesen, was ich hier schreib: über den Niemand in der Literatur (Göttingen: Wallstein, 1998).

Hamacher, Werner, Premises: Essays on Philosophy and Literature from Kant to Celan (Stanford: Stanford University Press, 1999).

Heidegger, Martin, Early Greek Thinking, trans. by David Farrell Krell and Frank A. Capuzzi (San Francisco: Harper \& Row, 1975).

Heidegger, Martin, Wegmarken. Gesamtausgabe, vol. 9 (Frankfurt: Klostermann, 1976).

Joris, Pierre, Paul Celan: Selections (London: University of California Press, 2005).

Lyon, James K., Paul Celan and Martin Heidegger: An Unresolved Conversation 19511970 (Baltimore: The Johns Hopkins University Press, 2006).

Meinecke, Dietlind, Wort und Name bei Paul Celan. Zur Widerruflichkeit des Gedichts (Bad Homburg: Verlag Gehlen, 1970).

Menningshaus, Winfried, Magie der Form (Frankfurt am Main: Suhrkamp Verlag, 1980).

Olson, Anders, "Spectral Analysis. A commentary on 'Solve' and 'Coagula,", trans. by Hanna Kalter Weiss, in Word Traces, ed. by Aris Fioretos (Baltimore: Johns Hopkins University Press, 1994).

Tobias, Rochelle, "The Ground Gives Way: Intimations of the Sacred in Celan's 'Gespräch im Gebirg,', in MLN, 114 (1999), 567-589. 